\title{
SALINAS DA MARGARIDA: VOZES ANCESTRAIS, TRADICIONALIDADE E SABERES DO MAR
}

\section{ARTIGO ORIGINAL}

SULZART, Silvano ", SANTOS, Diana Bomfim ${ }^{2}$, SANTOS, Francisco Barbosa dos ${ }^{3}$, SOUZA, Luciene de Jesus Santos ${ }^{4}$

SULZART, Silvano. Et al. Salinas Da Margarida: Vozes Ancestrais, Tradicionalidade E Saberes Do Mar. Revista Científica Multidisciplinar Núcleo do Conhecimento. Ano 06, Ed. 05, Vol. 07, pp. 184-216. Maio de 2021. ISSN: 2448-0959, Link de acesso: https://www.nucleodoconhecimento.com.br/educacao/saberes-domar, DOI: 10.32749/nucleodoconhecimento.com.br/educacao/saberes-do-mar

\section{RESUMO}

O presente artigo apresenta reflexões iniciais de uma pesquisa em andamento no município de Salinas da Margarida - Ba, buscando realizar um levantamento sobre as produções acadêmicas realizadas neste território, bem como refletir sobre os aspectos da tradicionalidade, ancestralidade e a identidade cultural que permeia o cotidiano desta cidade e os saberes ancestrais carregados pelos Senhores e Senhoras do Mar. Chamamos de Senhores e Senhoras do Mar, os colaboradores desta pesquisa (pessoas que foram entrevistadas). Buscamos dialogar com diferentes autores e pesquisadores, tais como: Castellucci (2010), Diegues (1998) Gomes (2015),

\footnotetext{
${ }^{1}$ Doutorando em Difusão do Conhecimento (UFBA), Mestre em Educação (UNEB).

${ }^{2}$ Licenciada em Letras com Espanhol (Unijorge).

${ }^{3}$ Licenciado em História (UNEB).

${ }^{4}$ Licenciada em História (UNEB).
}

RC: 84996

Disponível em: https://www.nucleodoconhecimento.com.br/educacao/saberes-do-mar 
Kuhn,(2019), Caetano (2013), Menezes (2013), Thomé (2009), Sacramento (2019), Sulzart (2016), Pedrão (2011), Almir (2010) na perspectiva de entendermos os aspectos da ancestralidade, da maritimidade e da história de Salinas da Margarida. A pesquisa nasceu das inquietações dos professores no Coletivo Saberes do Mar, um coletivo que reúne professores e pesquisadores sobre a história, a cultura e a ancestralidade em Salinas da Margarida e Região. De cunho etnográfico, foram realizadas 20 entrevistas narrativas com os Senhores e Senhoras do Mar, pessoas com idade entre 68 a 114 anos de idade no município de Salinas da Margarida. As entrevistas foram gravadas e depois transcritas para serem analisadas, onde buscouse o sentido de pertencimento impregnado nas narrativas, como também compreender as riquezas ancestrais guardadas nas memórias e nos discursos destes Senhores e Senhoras do Mar.

Palavra Chaves: Ancestralidade, Quilombolas, Maritimidade, Salinas da Margarida.

\section{INTRODUÇÃO: UMA CIDADE DE SAL, COM FLORES POR TODOS OS LADOS}

Elas saem pela manhã, bem antes do sol nascer e da maré subir.

Elas pescam, catam os mariscos, tratam os peixes, cuidam da casa, educam seus filhos e filhas e tiram o sustento do MAR.

Elas conhecem os segredos da maré, onde podem encontrar mariscos, como andar no manguezal, como tirar ostras, sururus, pegar aratu, siri, peixes e camarões. São saberes ancestrais que somente as mulheres do mar dominam. A cultura do mar nos constitui, revela e desvela nossa identidade, diz quem somos, de onde somos e como somos.

Dominar os saberes das águas, os saberes da pesca, os saberes do mar, os saberes dos movimentos das ondas e da maré e os saberes do tempo do mar, não é algo que se aprende na escola, mas nas águas das marés, entre lágrimas, histórias e cantorias. "Minha jangada vai sair pro mar, vou trabalhar, meu bem querer, se Deus quiser

RC: 84996

Disponível em: https://www.nucleodoconhecimento.com.br/educacao/saberes-do-mar 
quando eu voltar do mar, Um peixe bom eu vou trazer" já nos dizia Dorival Caymmi.

Alguns Mulheres do Mar dizem: Odoya lemanjá! Salve a Senhora das águas! E caminham por entre as correntezas, andam nas águas, puxam redes, sobrevivem do mar, vivem no mar e para o mar.

As mulheres que tiram ouro do mar dominam os saberes das águas aprendidos com suas mães, avós, tios e tias ... aprendidos ali, no vai e vem das ondas, na maré, na lama e no manguezal .Paulo Freire nos ensinou que : "Não há saber mais, ou saber menos, há saberes diferentes".

E as Mulheres que tiram Ouro do Mar, são mulheres forjadas nas ondas e tempestades e crescem com a força das marés. Cuidam do mar, respeitam a maré ... As águas do mar são indivisíveis e a maré quando sobe, sobe para todo mundo. O mar é uma mãe. Silvano Sulzart

Ouvimos histórias marcadas pelas ancestralidades nos fez pensar o quanto precisamos resgatar na cidade de Salinas da Margarida, a história e a memória deste povo e deste lugar. Falamos aqui de uma ancestralidade que marca a vida de quem é do mar. O povo do mar e das águas aprende a nadar cedo, conhecer e reconhecer os peixes, os mariscos e o manguezal, mesmo antes de ir para a escola. A primeira escola de quem é do mar, são as águas, as correntezas marinhas, o barco, a rede, a vara de pescar... O mar é aprendizado, é um aprender construído no ritmo da maré para além dos livros.

Falamos neste artigo, de uma ancestralidade que consegue perceber a mudança da maré, as correntezas das águas e enxergar cardumes submersos, que somente um olhar apurado, consegue notá-los no mar. Falamos também de uma ancestralidade que se fundamenta na construção desta cidade, dos pescadores e marisqueiras, dos vendedores de peixes, dos pastores e evangelistas, dos padres e freiras, dos professores e professoras, dos médicos e enfermeiros e enfermeiras, das 
benzedeiras, mães e pais de santos que ajudaram a construir este paraíso que carrega no nome, a força da juventude e da beleza - Salinas da Margarida.

Os autores deste texto, são professores que nasceram e foram criados no mar. Silvano Sulzart é filho de pescador, escreveu um filho intitulado de "O Pescador e o Poder da Gratidão e o Livro "Docência das águas: diversidade cultural, maritimidade e travessias na llha de Itaparica". Sulzart é professor e nasceu praticamente no mar, em Mar Grande. Francisco Barbosa dos Santos é professor de História, nasceu em Salinas da Margarida é também pescador e agricultor. Francisco é apaixonado por Salinas da Margarida a tal ponto, que escreveu seu TCC- Trabalho de Conclusão de Curso com o título de "O Processo De Emancipação Política De Salinas Da Margarida No Ano De 1962", como requisito para a conclusão do curso de licenciatura em história pela Universidade do Estado da Bahia, em 2015. Parte do texto deste artigo nasceu também das pesquisas de Francisco no curso de história.

Já Luciene de Jesus Santos Souza, criada na Enseada do Paraguaçu, é formada também em História e atua como professora desde a sua juventude na comunidade de Cairu onde casou-se. Luciene ama ser professora e é apaixonada por Salinas da Margarida. E, Diana Bomfim Santos que é a professora licenciada em Língua Portuguesa, amante das letras, apaixonada pelo mar, tem suas origens em Salinas da Margarida. O lugar onde nascemos e crescemos nos constitui - somos do mar e o mar nos pertence.

Ao escrever sobre Salinas da Margarida, falamos de nós mesmos, falamos de quem somos, falamos dos nossos ancestrais, falamos no presente, falamos do passado, falamos de homens e mulheres que vieram antes de nós e nestas águas, marcaram suas vidas - isso é ancestralidade.

RC: 84996

Disponível em: https://www.nucleodoconhecimento.com.br/educacao/saberes-do-mar 
Para Oliveira (2007), a ancestralidade é uma categoria de relação, ligação, inclusão, diversidade, unidade e encantamento. Ela, ao mesmo tempo, é enigmaancestralidade e revelação-profecia. Indica e esconde caminhos. A ancestralidade é um modo de interpretar e produzir a realidade. Ela é um instrumento ideológico (conjunto de representações) que serve para construções políticas e sociais (p. 257). Já para Lopes (2004 p. 59), ancestral remete a antepassado e "o ancestral é importante e venerado porque deixa uma herança espiritual, contribuindo assim para a evolução da comunidade ao longo da sua existência". Eu não sou eu, eu sou as ondas da maré de março, o casco incrustado das canoas, sou a rede remendada dos pescadores, sou o caminho no manguezal, sou o porto dos barcos e o mastro que sustenta a vela dos saveiros...eu sou do mar e o mar é meu. Tal poetização que traçamos neste início de texto, justifica-se para marcar a nossa ancestralidade.

Neste sentido, percebemos e valorizamos todas as ancestralidades. E ao olhar para a nossa história e a nossa gente, não há como negar que herdamos riquezas inigualáveis: saberes do mar, saberes da terra, saberes da religiosidade, saberes da pesca, saberes da navegação, saberes do tempo da maré, saberes de diversas ancestralidades. Salinas da Margarida é este lugar ancestral, carregado pelas forças das águas.

Segundo o Site da Prefeitura Municipal de Salinas da Margarida, o município de Salinas da Margarida possui $65 \mathrm{~km}^{2}$ :

Tabela 01- Área do Município de Salinas da Margarida

\begin{tabular}{|l|l|l|l|}
\hline ÁREA & LATITUDE SUL & LONGITUDE OESTE & ÁREA CONTINENTAL \\
\hline $148,33 \mathrm{~km}^{2}$ & $12^{\circ} 52^{\prime} 16^{\prime \prime}$ & $38^{\circ} 45^{\prime} 52^{\prime \prime}$ & $65 \mathrm{~km}^{2}$ \\
\hline
\end{tabular}

Fonte: autores.

RC: 84996

Disponível em: https://www.nucleodoconhecimento.com.br/educacao/saberes-do-mar 
CONHECIMENTO ISSN: 2448-0959 https://www.nucleodoconhecimento.com.br

Salinas da Margarida é constituída pelas comunidades de Dendê (Porto da Telha), Encarnação de Salinas, Cairu, Conceição de Salinas e Barra do Paraguaçu. Vale ressaltar que Mutá, Pirajuia e Cações não fazem parte da cidade de Salinas da Margarida e sim, de Jaguaripe.

Figura 01- Mapa de Salinas da Margarida

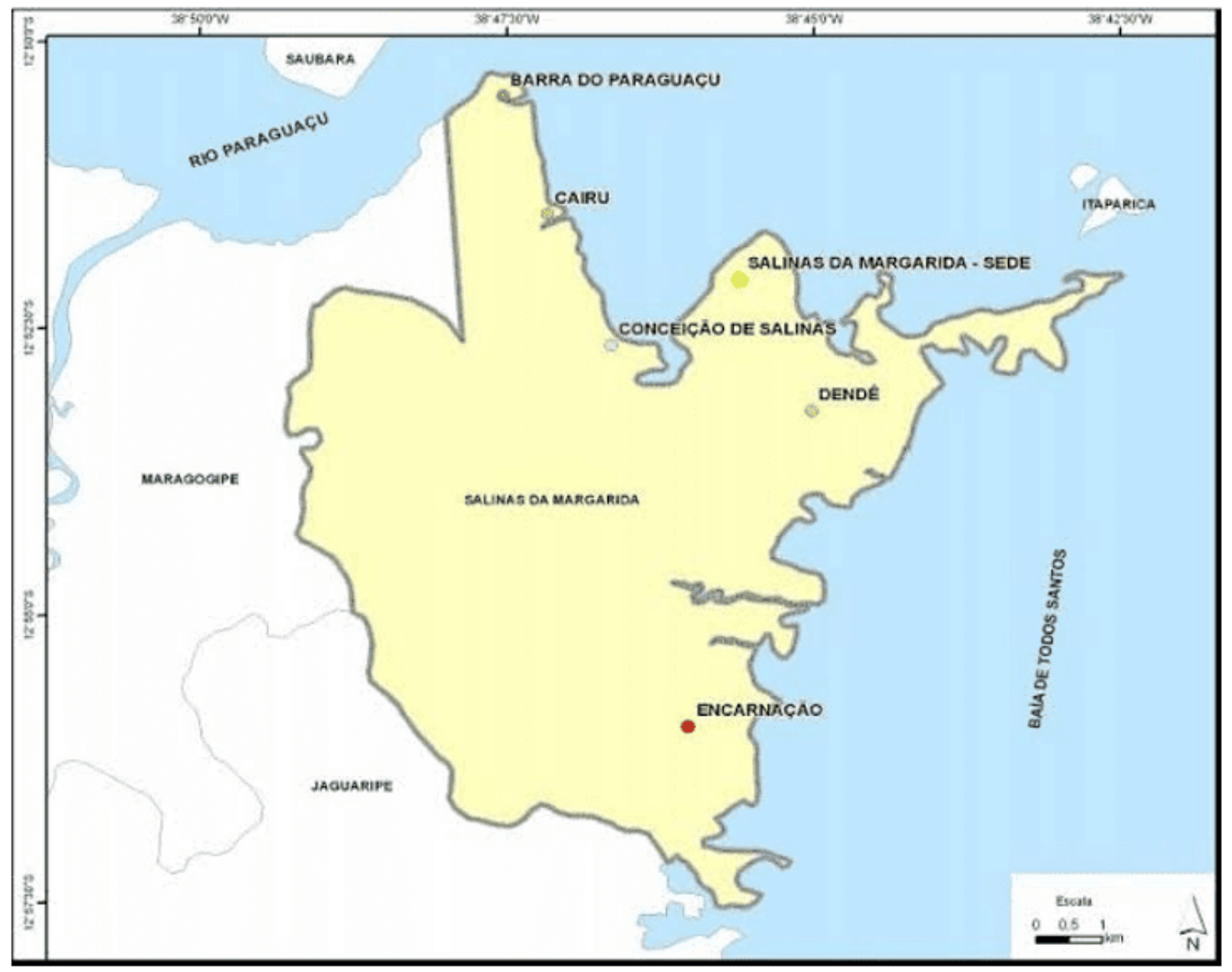

Fonte: COPQUE, 2010.

RC: 84996

Disponível em: https://www.nucleodoconhecimento.com.br/educacao/saberes-do-mar 
Segundo dados do IBGE - Instituto Brasileiro de Geografia e Estatística (2020), Salinas da Margarida tem uma população estimada em 15.862 habitantes. A Taxa de escolarização das pessoas com idade de 6 a 14 anos de idade é 97,9\%. O Índice de Desenvolvimento Educacional para os anos iniciais do ensino fundamental é de 4,4 (2017). Dados importantes, sinalizando que o contexto educacional da cidade avança para melhorias significativas.

No centro de Salinas da Margarida, voltada para a Baía de Todos os Santos, encontrase a Igreja de Nossa Senhora do Carmo, cuja construção foi determinada pelo Comendador Manoel de Sousa Campos, que faleceu antes mesmo do início das obras. A Igreja foi inaugurada em 1914. Francisco Borges de Barros, em seu Dicionário Geográfico e Histórico da Bahia a considera "indubitavelmente a mais bela do Recôncavo e do interior do Estado". Anualmente, em 16 de julho, celebra-se a Festa de Nossa Senhora do Carmo. Festa com novenário e com devotos de todas as comunidades de Salinas da Margarida.

Figura 02- Igreja de Nossa Senhora do Carmo/Salinas da Margarida

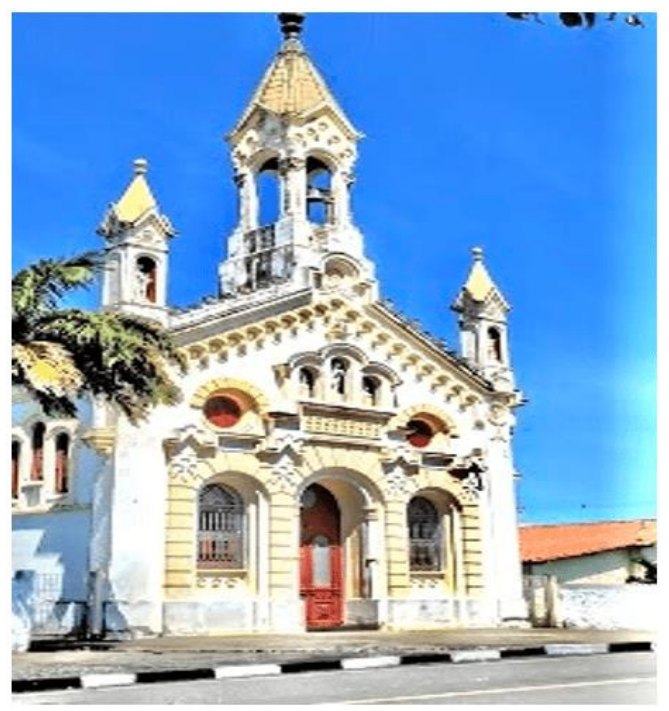

Fonte: Arquivo dos Autores.

RC: 84996

Disponível em: https://www.nucleodoconhecimento.com.br/educacao/saberes-do-mar 
CONHECIMENTO ISSN: 2448-0959 https://wWw.nucleodoconhecimento.com.br

Uma das primeiras dificuldades para quem deseja conhecer a história do município de Salinas da Margarida é justamente descobrir a verdadeira origem de seu nome, ou melhor, de parte dele, pois não existe qualquer dúvida que a palavra Salinas se refere tão somente a produção do sal é resultado da sua exploração. Pode-se afirmar com relativa segurança que antes do comendador Manoel de Souza Campos iniciar industrialmente o aproveitamento dessa riqueza marinha a denominação ainda não estava integrada à área territorial.

Figura 03 - Transporte do Sal em Salinas

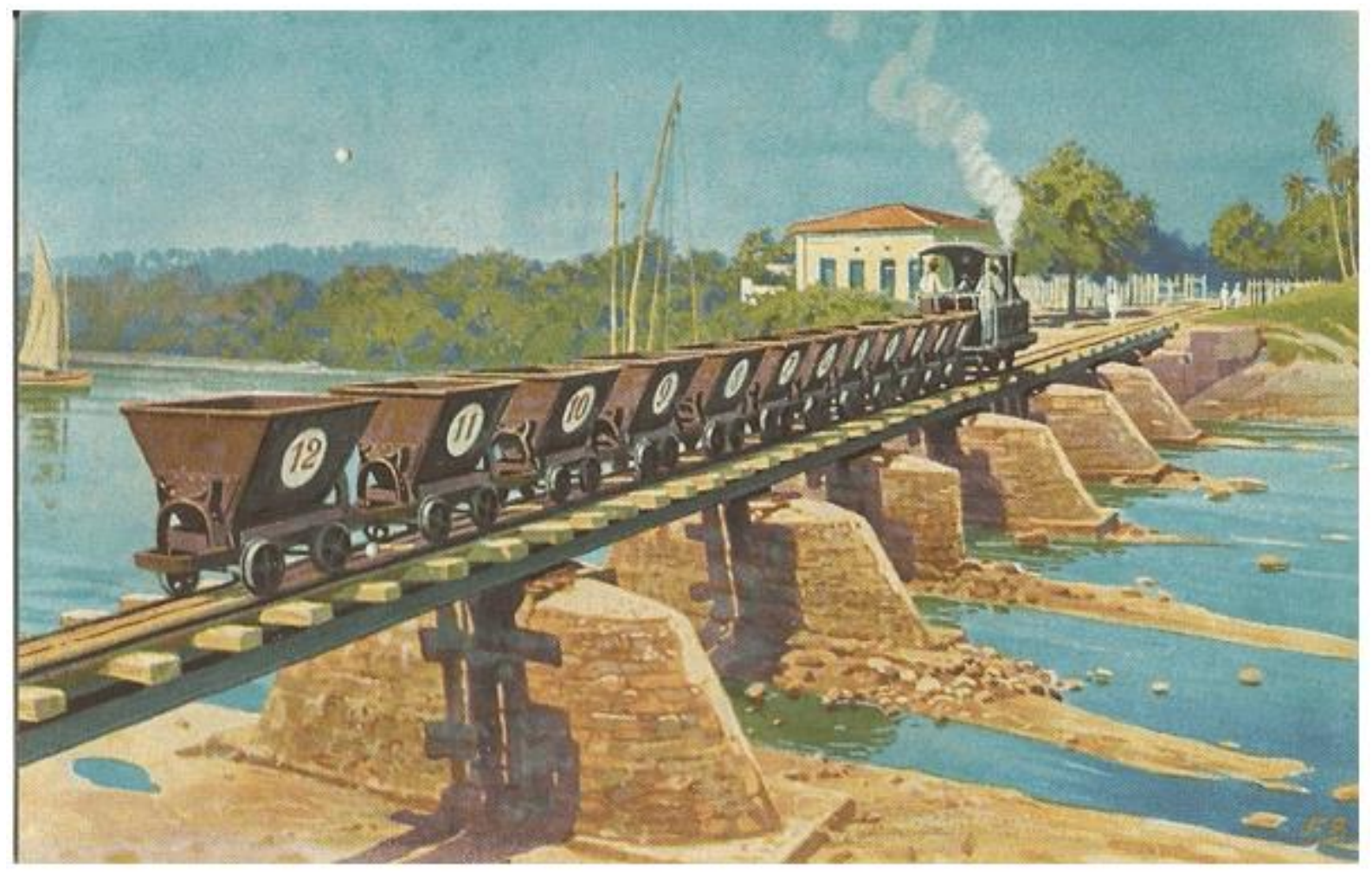

Fonte: Blog IBAHIA, 2021.

Salinas da Margarida é um município que foi desmembrando da cidade de Itaparica em 1962, neste período a cidade de Itaparica fora desmembrada em três cidades: Salinas da Margarida, Vera Cruz e Itaparica.

$\mathrm{RC}: 84996$

Disponível em: https://www.nucleodoconhecimento.com.br/educacao/saberes-do-mar 
Existem várias versões sobre a origem do nome da cidade de Salinas da Margarida, umas delas refere-se ao nome Margarida, que para alguns tem um tom romântico, referindo-se que tal nome, surge na homenagem que Manoel de Souza Campos fez para a sua esposa, colocando o nome da mesma na cidade em 1962, no entanto não existe comprovação desse fato, pois o nome da esposa do Comendador Manoel de Souza Campos era D. Guilhermina Gomes Marelim.

Neste sentido, nota-se claramente que a versão histórica ligada ao comendador e sua esposa, sobre o nome do município - Salina da Margarida não procede. No entanto, realizando diversas pesquisas, encontramos duas questões que possivelmente colaboraram para a constituição do nome da cidade: uma foi o sal que era abundante na região e outra a enorme quantidade de flores chamadas de margaridas.Latim margarita (margarida) é uma palavra que vem do latim, que significa pérola, popularmente chamada de "olho do dia", pelo fato desta flor desabrochar sempre ao nascer do sol. Uma suposição é que o nome margarida tenha surgido devido às milhares de margaridas que embelezavam a cidade antes do povoamento.

Figura 04 - Margarida Branca

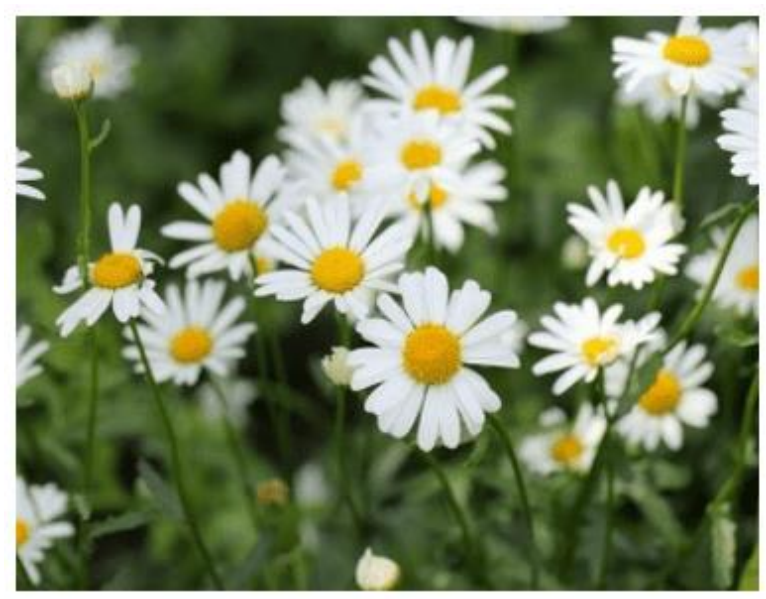

Fonte: Arquivo dos Autores.

RC: 84996

Disponível em: https://www.nucleodoconhecimento.com.br/educacao/saberes-do-mar 
A margarida é uma flor simples, que nasce em diferentes tipos de solo. Chamada de flor do mar, da juventude e das donzelas. A flor também está ligada aos sentimentos de paz e afeto. Existem tipos de flores que recebem o nome de margaridas, as mais populares são as flores brancas e amarelas, as quais notamos em abundância na região da cidade de Salinas da Margarida.

Em 1889 o Comendador Manoel de Souza Campos implantou um sistema para a produção de sal em Salinas da Margarida, semelhante aos de Aveiro em Portugal. Em Aveiro produzia-se sal para consumo na cozinha, mas em especial para salgar o bacalhau, um dos recursos naturais que a região explorava comercialmente naqueles idos.

O Sal era extraído em Salinas da Margarida, ensacado e levado para a Cidade de Salvador, no entanto, tal atividade econômica não teve muito sucesso, mas deixou suas marcas históricas na cidade.

Salinas da Margarida passou a ser distrito da cidade de Itaparica em 15/11/1901, neste período a cidade de Itaparica, correspondia a toda a llha de Itaparica e também a região onde hoje é a cidade de Salinas da Margarida. Em 27 de julho de 1962, quando o Sr. Manoel Dias de Albuquerque redigiu a Proposta de Emancipação, apresentando-a ao deputado Estadual Padre Luís Soares Palmeira, que levou o projeto para votação na Assembleia Legislativa do Estado da Bahia, para conseguir a aprovação do mesmo.

Amigo do Padre Luís Soares Palmeira, que conheceu na Cidade de Vitória da Conquista, quando lá esteve servindo ao Tiro de Guerra, (Manuel Albuquerque pertencer às fileiras do Exército) e sendo o Padre Palmeira então Deputado Estadual, por seu intermédio foi apresentado à Assembleia Legislativa o projeto de Lei $n$.

RC: 84996

Disponível em: https://www.nucleodoconhecimento.com.br/educacao/saberes-do-mar 
1945/61, que criava o município de Salinas da Margarida, desmembrando-o da cidade de Itaparica.

Além do Padre Palmeira, autor do projeto emancipacionista, assinaram o documento os Deputados Mário Padre, Aloisio Rocha, Bião de Cerqueira, Juarez de Sousa, Luís Ataíde, Rocha Pires, Nicolau Suerdieck, Valter Lomanto, Herval Soledade, Wandick Badaró, Aloísio Short, Oldack Neves, Bolivar Santana, Carlos Facó, Rabi Resedá, Ana Oliveira Acioli Vieira, Renato Leoni e Djalma Bessa.

Neste processo, o distrito de Salinas foi emancipado da cidade de Itaparica através do decreto da lei Estadual n 1755, de 27/07/1962, sancionado pelo Governador Juracy Magalhães e pelo Desembargador Adalicio Nogueira, conforme consta no Diário Oficial do Estado, edição de 31 de julho de 1962 criando a cidade de Salinas da Margarida.

A divisão política da cidade de Itaparica em 3 em 1962 ( Salinas da Margarida, Vera Cruz e Itaparica) não foi algo fácil e tão pouco rápido. O projeto da divisão política da cidade de Itaparica tramitou durante 15 (quinze) anos na Câmara dos Deputados da Bahia. Itaparica, com o fim da indústria do sal já não tinha interesse em Salinas e a região do Mar Grande, em Vera Cruz, estava desamparada pela gestão itaparicana. Naquela época (1962) a emancipação de Salinas e do Mar Grande (Vera Cruz) foi um alívio para Itaparica.

\section{METODOLOGIA: OLHARES SOBRE A TERRA E SOBRE O MAR}

A presente pesquisa fundamenta-se na fenomenológica e na hermenêutica inspirada na etnografia. No campo da pesquisa social a fenomenologia-hermenêutica contribui na busca de sentido/significado ao descrever a realidade vivida pelos sujeitos, no caso desta pesquisa (homens e mulheres com idade entre 68 a 114 anos, que chamaremos

$\mathrm{RC}: 84996$

Disponível em: https://www.nucleodoconhecimento.com.br/educacao/saberes-do-mar 
de Senhores e Senhoras do Mar, para preservar a identidade dos mesmos. $\mathrm{Na}$ pesquisa, utilizamos os seguintes instrumentos de coleta de dados: 1- Entrevista Narrativa Análise Documental, Pesquisa Bibliográfica e a 3-Observação e Registro de Campo.

As entrevistas aconteceram entre janeiro e março de 2021, no entanto, o grupo já desenvolvia pesquisas e estudos desde a graduação em História de Francisco Barbosa, ocorrida em Salinas da Margarida pela Universidade do Estado da Bahia, em 2015, quando Francisco inicia seus estudos sobre a História e a Cultura de Salinas da Margarida.

\subsection{A ENTREVISTA NARRATIVA:}

A entrevista narrativa permite a compreensão das singularidades e particularidades dos sujeitos, pois o narrador incorpora as coisas narradas à experiência dos seus ouvintes, narra suas experiências, descreve o mundo vivido por si mesmo e esta narrativa traz as insígnias do narrador, "assim se imprime na narrativa a marca do narrador, como a mão do oleiro na argila do vaso" (BENJAMIN, 1994, p. 204).

Nesta pesquisa, optamos pelo uso das entrevistas narrativas, por entender que o processo narrativo coadunava com a metodologia utilizada.

Ao fim da escuta das narrativas dos Senhores e Senhoras do Mar, todo o material é transcrito e discutido entre o sujeito participante e os pesquisadores, que, a partir de então, farão um mergulho analítico nas entrevistas. Assim, o nosso trabalho é colher narrativas, memórias e falas e tornar todo este material como matéria-prima para o nosso trabalho e para a nossa própria reflexão. A entrevista narrativa é, sobretudo, uma forma dialógica, onde o sujeito é convidado pelo pesquisador a considerar suas experiências passadas, de forma espontânea, e, desse modo, vai se desvelando,

RC: 84996

Disponível em: https://www.nucleodoconhecimento.com.br/educacao/saberes-do-mar 
narrando uma história em que ele mesmo é autor, ator, coadjuvante e telespectador de si mesmo. Ao narrar a sua própria experiência ou aquela que é vivida pelos outros, o narrador também incorpora as experiências dos ouvintes. Neste momento da narrativa, acontece a construção de novos significados, tanto para o narrador quanto para o ouvinte.

$\mathrm{Na}$ entrevista narrativa, o sujeito entrevistado é o centro e foco principal da pesquisa, sua voz, seus argumentos, suas ideias e pensamentos, são valorizados da forma como são colocados para o pesquisador.

Assim, seguindo as fases da entrevista proposta por Jovchelovitch e Bauer (2010, p. 110), por acreditar que estes passos são fundamentais para se obter uma entrevista dentro dos padrões científicos e que se enquadre na perspectiva teórica de uma entrevista narrativa. Assim, as entrevistas narrativas vão considerar as seguintes etapas: preparação, iniciação, narração central, fase de perguntas e a fala conclusiva.

Ao narrar sua própria vida, Os Senhores e Senhoras do Mar narram também a vida social e coletiva que o cotidiano desvela.

Assim, ao narrarem as suas experiências de vida em Salinas da Margarida, os sujeitos (homens e mulheres entre 68 a 114 anos) não assumem uma perspectiva linear e, sim, traçam a trama complexa que constitui a suas histórias de vidas, em suas itinerâncias e ancestralidades. Para Souza (2006), o trabalho de investigação que se utiliza das entrevistas narrativas, centrado na reconstrução de histórias, tem propiciado a reflexão sobre as histórias de vida, de formação e de profissionalização, bem como sobre as histórias e culturas dos lugares, tendo em vista que tempo, memória, espaço e história caminham juntos.

A narrativa de si e das experiências vividas ao longo da vida caracterizam-se como processo de formação e de conhecimento,

RC: 84996

Disponível em: https://www.nucleodoconhecimento.com.br/educacao/saberes-do-mar 
porque se ancora nos recursos experienciais engendrados nas marcas acumuladas das experiências construídas e de mudanças identitárias vividas pelos sujeitos em processo de formação e desenvolvimento. (SOUZA, 2006, p. 136)

Narrar a própria vida nos auxilia a recuperar as experiências vividas que marcaram efetivamente a trajetória do sujeito, ao longo do seu percurso vivido. Assim, ao narrar sobre si, sua realidade, seu cotidiano e suas vivências, o sujeito constrói e reconstrói o próprio discurso desvelando as marcas de uma vida, de um contexto social, suas memórias e seu pertencimento. Cada entrevista foi um achado entre as águas.

Neste sentido, vale ressaltar que, ao discorrer sobre a análise compreensivainterpretativa das narrativas, Souza (2014, p. 42) reforça que: "são diversas as possibilidades de análise com fontes narrativas, (auto)biografias, memórias e com escritas em processo de formação".

\subsection{OS SENHORES E SENHORAS DO MAR}

$\mathrm{Na}$ presente pesquisa, entrevistamos 20 Senhores e Senhoras do Mar de idade entre 68 a 114 anos de idade. Entrevistamos pescadores, parteiras, benzedeiras, marisqueiras, políticos e personalidades de Salinas da Margarida em quadro distritos diferentes. Colocamos pseudônimos nos participantes da pesquisa para preservar os mesmos, no entanto a comunidade e a idade permaneceram.

Tabela 02 - Entrevistados - Fonte: Arquivos da Pesquisa.

\begin{tabular}{|c|c|c|}
\hline Nome & Idade & Distrito de Salinas \\
\hline 1. Senhora do Mar Aratu & 89 & Salinas/Sede \\
\hline 2. Senhora do Mar Mangue Vermelho & 78 & Salinas/Sede \\
\hline 3. Senhor do Mar Siri & 98 & Salinas/Sede \\
\hline 4. Senhora do Mar Mangue Branco & 90 & Salinas/Sede \\
\hline
\end{tabular}

RC: 84996

Disponível em: https://www.nucleodoconhecimento.com.br/educacao/saberes-do-mar 


\begin{tabular}{|c|c|c|}
\hline 5. Senhora do Mar Tainha & 82 & Conceição de Salinas \\
\hline 6. Senhor do Mar Arraia & 88 & Conceição de Salinas \\
\hline 7. Senhor do Mar Ostra & 72 & Conceição de Salinas \\
\hline 8. Senhor do Mar Canoa & 74 & Conceição de Salinas \\
\hline 9. Senhor do Mar Vela & 84 & Conceição de Salinas \\
\hline 10. Senhora do Saveiro & 78 & Conceição de Salinas \\
\hline 11. Senhora do Mar Vara de Pescar & 91 & Conceição de Salinas \\
\hline 12. Senhora do Mar Taineira & 98 & Barra do Paraguaçu \\
\hline 13. Senhora do Mar Marisqueira & 89 & Barra do Paraguaçu \\
\hline 14. Senhora do Mar Camarão & 91 & Barra do Paraguaçu \\
\hline 15. Senhora do Mar Aratu & 80 & Barra do Paraguaçu \\
\hline 16. Senhora do Mar Sardinha & 68 & Cairu \\
\hline 17. Senhora do Mar Rede & 114 & Cairu \\
\hline 18. Senhora do Mar do Porto & 72 & Cairu \\
\hline 19. Senhor do Mar do Manguezal & 90 & Cairu \\
\hline 20. Senhor do Mar Peguari & 82 & Cairu \\
\hline
\end{tabular}

Fonte: autores.

\section{PARTEIRAS DE CAIRU: ANCESTRALIDADE E SAÚDE}

Percorremos parte dos $65 \mathrm{~km}^{2}$ do município de Salinas da Margarida, visitando os distritos de Cairu, Barra do Paraguaçu e Conceição de Salinas buscando vozes ancestrais que pudessem nos ajudar a compreender um pouco mais sobre este território e sobre as marcas do viver e sobreviver do e no mar, e sobre a nossa ancestralidade .Aos poucos fomos descobrindo Senhores e Senhoras, que aqui chamaremos de Senhores e Senhoras do Mar, pessoas carregadas de sabedoria, conhecimento e experiência de vida.

RC: 84996

Disponível em: https://www.nucleodoconhecimento.com.br/educacao/saberes-do-mar 
As nossas andanças e travessias levou-nos a dialogar com uma parteira no distrito de Cairu, um lindo e belo distrito da cidade de Salinas da Margarida. O nome Cairu é indígena e vem do Tupi, tendo como significado: "árvores de folhas escuras".

A Parteira de Cairu é uma senhora negra, cabelos grisalhos, com a voz já meio rouca, uma senhora bem vaidosa, que nos atendeu após arrumar os cabelos e colocar um lindo vestido. A parteira Senhora do Mar Sardinha nos narrou, como dezenas de crianças de Cairú e Conceição de Salinas nasciam em uma época em que Salinas da Margarida não tinha hospital.

Nesta região ou nascia pelas mãos das parteiras ou velejava até Salvador. Diversas crianças já nasceram na travessia Salinas da Margarida $\times$ Salvador na antiga lancha Albatroz.

O ofício de parteira ou de partejar é uma das práticas mais antigas da humanidade, pois antes de existirem hospitais e maternidades, eram as parteiras que "traziam os meninos e as meninas ao mundo". As parteiras são detentoras de um saber tradicional milenar. Tradição oral de transmissão de conhecimentos, costumam aprender este ofício com outras mulheres da família: suas mães, avós e tias. As parteiras eram chamadas sempre que uma grávida estava prestes a parir. Muitas vezes as parteiras tinham que sair de madrugada de canoa, quando não era de canoa era andando ou a cavalo para socorrer as mulheres e seus filhos.

A Senhora do Mar Sardinha, tem 68 anos e foi parteira no distrito de Cairu de Salinas da Margarida. A Senhora do Mar Sardinha narra que fez muitos partos e que aprenderá a ser parteira com sua avó e com Dona Valdelice. Dona Valdelice foi uma parteira de Salinas da Margarida muito famosa. No início a Senhora do Mar Sardinha não queria ser parteira, mas a avó sempre a chamava para observar os partos e aos

RC: 84996

Disponível em: https://www.nucleodoconhecimento.com.br/educacao/saberes-do-mar 
poucos ela foi aprendendo a fazer partos, até fazer seu primeiro parto. Depois disso, ajudou dezenas de mulheres da região em seus partos.

\section{BENZEDEIRAS DE CONCEIÇÃO DE SALINAS: ANCESTRALIDADE E RELIGIOSIDADE}

Conceição de Salinas é um distrito belíssimo com uma orla maravilhosa, onde podese observar as chegadas e saídas de pescadores e marisqueiras em suas canoas e barcos para o mar. Em Conceição de Salinas, também se encontra a capela de Nossa Senhora da Conceição. A capela possui planta de nave única, com capela-mor e sacristias laterais, data de 1717.

Figura 05- Capela de Nossa Senhora da Conceição/Conceição de Salinas

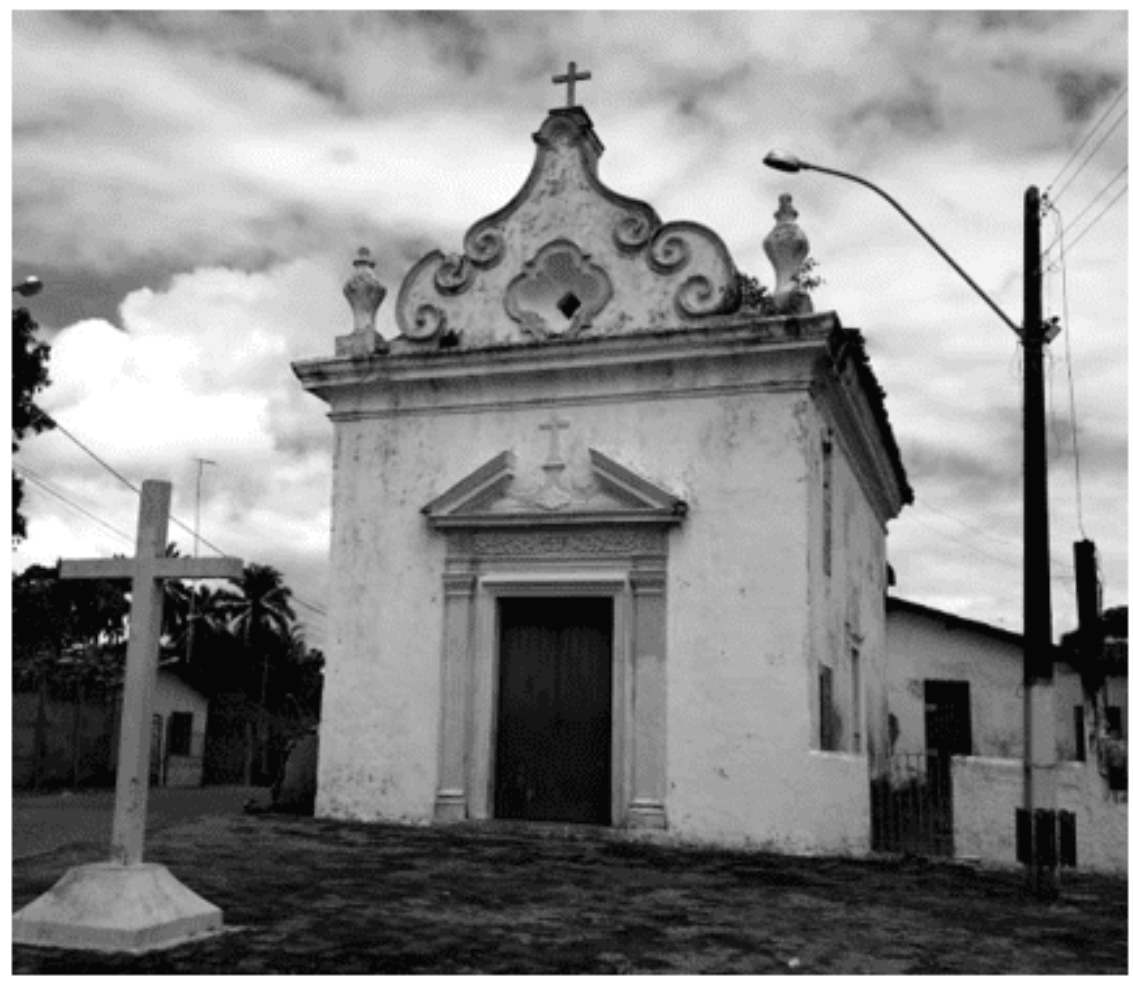

Fonte - Arquivos dos Autores.

RC: 84996

Disponível em: https://www.nucleodoconhecimento.com.br/educacao/saberes-do-mar 
Em Conceição de Salinas, ouvimos narrativas ancestrais sobre a sobrevivência da pesca, sobre as práticas religiosas e sobre o sentido de pertencimento. Conceição de Salinas não é só um distrito de Salinas, é o lugar onde a vida se produz e se constituiu historicamente sobre o mar. O mar é mãe, pai, amigo, companheiro e companheira. O mar é vida, sustento e fortaleza, o mar foi a infância, adolescência, vida adulta e a transcendência do povo que tem as marcas do mar: Salinas.

Uma das Senhoras do Mar, que é benzedeira mostrou-nos o quanto a religiosidade é presente em Salinas da Margarida. E logo, ficamos em silêncio para ouvir a Senhora do Mar Ostra fazendo sua reza de "olhado" ou "contra o mau olhado":

Se foi mulher, se foi garota, ou se foi velha, ou se foi negra, ou se foi menino que te botou olhado no teu cabelo, na tua cor, nos teus olhos, na tua boniteza, na tua feiura, na tua magreza, nos teus braços, nas tuas pernas, na tua esperteza. Para que não me dissesse, que eu te curaria com os poderes de Deus e da Virgem Maria, com um Padre Nosso e uma Ave Maria, (Nome da pessoa), Deus te fez, Deus te criou, Deus te acanhe, quem te acanhou. Olhado vivo, olhado morto, olhado excomungado vai-te pela vazante da maré! (Entrevista - Senhora do Mar Ostra)

Ao ouvir a reza ficamos encantados com o conhecimento, com a simplicidade, com a fé. Silvano Sulzart lembrou-se das muitas benzedeiras da llha de Itaparica, de como muitas mães levavam seus bebês para serem benzidos. As rezas e os conhecimentos destas mulheres, fazem parte da nossa ancestralidade, carregados conosco parte desta história religiosa.

As rezas e benzimentos têm origem no período inicial da colonização do Brasil, e se mantém, principalmente, sobre uma base cultural religiosa mista em comunidades do nosso país. Salinas da Margarida é este lugar entre a terra e o mar, onde o vento sopra suave e a vida passa como as ondas do mar, e a maré vazante leva todos marés e infortúnios, dores e mágoas pelas rezas das suas benzedeiras, guardiãs desses grandes tesouros ancestrais.

RC: 84996

Disponível em: https://www.nucleodoconhecimento.com.br/educacao/saberes-do-mar 
A Senhora do Mar Mangue Vermelho que é uma grande líder espiritual, ela mesma, não se considera uma "Mãe de Santo", mas uma pessoa que faz o bem, que ajuda ao próximo, que se coloca à disposição da população.

Mulher Preta, de saberes ancestrais, benzedeira, a Senhora do Mar Mangue Vermelho narra que já percorreu todas as comunidades de Salinas, já ajudou muitos comerciantes e pessoas importantes. Em Salinas da Margarida, não se inaugurava "vendas" (pequenas lojas) e comércios sem que a Senhora do Mar Mangue Vermelho não fosse chamada para benzer. E a Senhora do Mar Mangue Vermelho, realizava suas orações, com folhas e rezas e a loja já estava pronta para receber a freguesia. Você já ouviu falar nessas mulheres? Nas mulheres que carregam o conhecimento das folhas, que rezam e expulsam doenças e coisas ruins? Se nunca ouviu precisa conhecer Conceição de Salinas e Senhora do Mar Mangue Vermelho que domina os saberes das rezas e os conhecimentos das plantas.

\section{CONCEIÇÃO DE SALINAS, COMUNIDADE TRADICIONAL SIM, QUILOMBOLA NÃO}

Terras habitadas pelos índios Tupinambás e pertencentes à Capitania dos Portos de Salvador, Estado da Bahia, Salinas da Margarida era dividida em duas: "Fazenda Conceição e Santa Luzia" adquiridas pelo comendador Manoel de Souza Campos, pessoa de grande prestígio no cenário político estadual.

Em 03 de fevereiro de 2017, Conceição de Salinas, foi certificada pela Fundação Palmares como uma comunidade remanescente de quilombolas, processo que se iniciou em 04 de fevereiro de 2015. Antes disso, não foram encontradas nenhuma pesquisa de mestrado ou doutorado, tão pouco registro na literatura que apontasse a comunidade de Conceição de Salinas, como uma área de remanescentes de quilombolas. Encontramos 18 pesquisas (mestrado e doutorado) de 2000 a 2021

RC: 84996

Disponível em: https://www.nucleodoconhecimento.com.br/educacao/saberes-do-mar 
realizadas em Salinas da Margarida e nenhuma pesquisa apontava Conceição de Salinas historicamente como território quilombola.

Segundo o Ministério da Cidadania, as comunidades quilombolas e remanescentes de quilombolas são comunidades com identidade cultural própria e se formaram dentro de um contexto histórico de luta pela sobrevivência contra a escravidão. No entanto, ao tratar especificamente do distrito de Conceição de Salinas e da Cidade de Salinas da Margarida, não encontramos indícios históricos de que nesta região, tenha existido comunidades quilombolas ou remanescentes de quilombolas.

Tal afirmação fundamenta-se nos estudos de Flávio dos Santos Gomes (1995), uma das maiores autoridades brasileiras sobre Mocambos e Quilombos, que retrata em seu livro, "Um Recôncavo, Dois Sertões E Varios Mocambos: Quilombos Na Capitania Da Bahia" (1575-1808), a história da nossa região relatando a resistência dos negros fugidos, notícias e ações de aquilombamento e as estratégias dos senhores de escravos e do estado para captura e manutenção da escravidão.

Flávio dos Santos Gomes já publicou/organizou mais de 39 livros, orientou mais de 20 pesquisas de mestrados e doutorado e em nenhum de seus estudos e pesquisas aponta a região de Conceição de Salinas como uma região quilombola.

Em uma de suas pesquisas, editada em 1995, Gomes (1995), cita, além do Rio Paraguassu, cidades vizinhas ao município de Salinas da Margarida, como Maragogipe, Jaguaripe, Nazaré e ainda a comunidade de Pirajuia, Distrito de Jaguaripe. Gomes (1995) traz os detalhes de sua pesquisa sobre os MOCAMBOS e QUILOMBOS nessas regiões. Porém o historiador, mesmo analisando o efeito do aquilombamento das cidades vizinhas e limítrofes de Salinas da Margarida, de 1575 a 1808, não aponta a presença da formação de Quilombos em Conceição de Salinas e nem na cidade de Salinas da Margarida.

$\mathrm{RC}: 84996$

Disponível em: https://www.nucleodoconhecimento.com.br/educacao/saberes-do-mar 
Neste contexto, notamos que a Comunidade de Conceição de Salinas é uma comunidade negra, de homens e mulheres marcados por uma ancestralidade negra, o que não quer dizer que a comunidade seja remanescente de quilombolas, negra sim, quilombola não. Por outro lado, compreendemos que como povo negro, sofremos diversas opressões neste país, e precisamos diuturnamente sobreviver ao racismo e aos tratamentos desiguais que sofremos e passamos como negros e negras.

Neste entendimento, nas 20 entrevistas que realizamos na cidade de Salinas da Margarida e na comunidade de Conceição de Salinas, não houve nenhuma narrativa ou memória por partes dos entrevistados Senhores e Senhoras do Mar, pessoas com idade entre 68 a 114 anos que narrasse memórias sobre ser Conceição de Salinas uma comunidade quilombola ou de remanescentes de quilombo. A escravidão findouse em 1888, há 133 anos atrás. Caso existissem remanescentes de quilombo nesta região certamente alguns dos Senhores e Senhoras do Mar teriam memórias, mas, no entanto, nenhum dos nossos entrevistados sinalizaram a existência de quilombo na região de Conceição de Salinas/Salina da Margarida, como nos narra o Senhor do Mar Canoa:

Minha mãe era filha daqui, (Conceição de Salinas) meu pai era de Santo Amaro, nunca ouvi dizer que aqui era quilombo. Lá no estaleiro que chama de Gravatar, dizem que algumas pessoas eram escravas, eram negros, mas daí em diante ...quilombo não ... (EntrevistaSenhor do Mar Canoa)

A legislação reconhece como critério para determinação de comunidades como quilombolas a autoidentificação. No entanto, em Conceição de Salinas, nas nossas caminhadas e travessias pelas ruas do distrito, dialogando com pescadores, marisqueiras, pastores, benzedeiras e pessoas da comunidade, as narrativas foram unânimes em não reconhecer a comunidade como quilombola. Negros sim, ancestralidade sim, imponderados sim, na defesa e na luta contra o racismo e toda opressão sim, mas quilombolas não.

$\mathrm{RC}: 84996$

Disponível em: https://www.nucleodoconhecimento.com.br/educacao/saberes-do-mar 
No levantamento realizado na Biblioteca Digital Brasileira de Dissertações e Teses BDTD que realizamos não encontramos nenhuma pesquisa de cunho histórico que pudesse apresentar elementos factuais da real existência de um quilombo na região de Salinas da Margarida. Na pesquisa encontramos 14 dissertações e 4 teses de doutorado utilizando o descritor "Salinas da Margarida". Nesta perspectiva, sentimos falta de dados e informações que pudessem confirmar a existência de um quilombo em Conceição de Salinas, mas nada fora encontrado e nenhum registro histórico, nem mesmo nas narrativas das ancestralidades que escutamos dos Senhores e Senhoras do Mar.

O tema sobre a existência de quilombo na Região de Salinas da Margarida chamou nossa atenção, uma vez que, pesquisando a História da Bahia e da Região da llha de Itaparica e da Baía de Todos os Santos, em momento algum nesta parte da Baía de Todos os Santos (Salinas da Margarida), encontramos registros (pesquisas) da existência de quilombos ou de quilombolas.

Francisco, professor de história do município de Salinas da Margarida, que foi aluno de Wellington Castellucci Junior, professor de História da Universidade do Estado da Bahia e uma das maiores autoridades sobre os estudos sobre a história da Baia de Todos os Santos, sobre a pesca das baleias e sobre a escravidão, lembra-se que o professor e pesquisador em uma de suas aulas afirmara não existir evidencias de quilombo na Região de Salinas da Margarida, tendo em vista a falta de elementos históricos ou informações encontradas.

Ao fazer a leitura e análise de Germani (2019) "Relatório Técnico Preliminar Comunidade Quilombola Pesqueira Conceição De Salinas" notou-se a falta de dados e fontes histórica e científica para o entendimento da comunidade de Conceição de Salinas, como quilombo, pois aos dialogarmos com a comunidade pelas ruas, praias, 
igrejas e centros religiosos era notório o espanto e a falta de identificação da comunidade com o pertencimento a remanescência quilombola.

Outra questão que fica claro é que nenhum historiador tenha apontado em seus estudos a presença de quilombo ou remanescentes de quilombolas na Região de Salinas da Margarida. Ubaldo Osório (1979), grande pesquisador da llha de Itaparica, não apresenta nenhum indício de quilombo nesta região, tendo em vista que Salinas da Margarida era distrito da Cidade de Itaparica.

Almir Oliveira (2000), escritor e pesquisador apaixonado por Salinas da Margarida em seu livro: Salinas da Margarida Notícias Histórica, não faz nenhuma menção sobre a existência de quilombo na região de Salinas da Margarida.

Neste sentido, chegamos a conclusão que não há dados numéricos, informações, documentação histórica e registros confiáveis que comprovem a existência de quilombolas na região de Conceição de Salinas/Salinas da Margarida. Partindo deste pressuposto, acreditamos que chamar uma comunidade de quilombola, sem que a mesma não tenha elementos históricos comprobatórios é deslegitimar a luta de tantas outras comunidades quilombolas pelo Brasil.

No entanto, a partir de 2015, utilizando-se da Convenção 169, da OIT, que instituiu a autodeterminação como requisito para ser considerada uma comunidade tradicional/quilombola, grupos de movimentos sociais do município de Salinas da Margarida, mobilizaram-se no intuito de tornar a Comunidade de Conceição de Salinas, uma comunidade quilombola e de remanescentes de quilombos. Neste sentido, mesmo que uma totalidade dos moradores de Conceição de Salinas, não se reconheçam, não saibam e nem se identifiquem como quilombolas, a comunidade foi certificada pela Fundação Cultural Palmares. A certificação foi instituída pela Portaria 
Número 62, de 31/01/2017, e publicada no Diário Oficial da União, em 03 de fevereiro de 2017.

Acredita-se que a ideia de quilombo em Conceição de Salinas, nasce a partir do academismo e do interesse particular de alguns grupos, não pela luta legítima contra a opressão, nem tão pouco para reparar os danos causados à nossa população negra, mas sim em benefício próprio.

Em uma Rede Social (Facebook), uma marisqueira de Conceição de Salina, denunciou as brigas internas do chamado Quilombo de Conceição. Tal briga deu-se pelas terras. A marisqueira de Conceição de Salina alegava que os dirigentes do "quilombo", deram suas terras para outras pessoas, que o desrespeito foi tanto, que a marisqueira teve que chamar a polícia para exigir suas terras de volta. A senhora que fez a narrativa em ambiente virtual, chamou a nossa atenção, pois alegava que não existiam em Conceição de Salinas 800 famílias, dados que sempre foram colocados por alguns grupos para legitimar a remanência quilombola na região. Alguns dias depois, a marisqueira apagou a publicação do Facebook.

Conceição de Salinas tem suas raízes na ancestralidade, na luta pela sobrevivência de homens e mulheres, pescadores e marisqueiras .Conceição de Salinas é o lugar aonde o sustento vem da maré, onde homens e mulheres vivem e sobrevivem do mar. Um lugar onde as águas salgadas parecem nunca secar, e os frutos do oceano são abundantes, uma terra onde todos os caminhos dão na maré, terra de gente que acredita em Deus, nos orixás, Conceição de Salinas é uma terra de fé.

A Pesquisa de Elionice Conceição Sacramento (2019) "Da Diáspora Negra Ao Território Das Águas: Ancestralidade e protagonismo de mulheres na comunidade pesqueira e quilombola Conceição de Salinas-BA" é uma pesquisa que desvela as lutas e trajetórias das mulheres em Conceição de Salinas. $O$ trabalho tem um cunho

RC: 84996

Disponível em: https://www.nucleodoconhecimento.com.br/educacao/saberes-do-mar 
poético, biográfico e etnográfico, que marca todo itinerário da pesquisa. Um trabalho que desvela uma trajetória de fortalecimento do protagonismo das mulheres nas comunidades pesqueiras.

No entanto, Sacramento (2019) ressalta em diversos parágrafos da sua pesquisa que sentiu dificuldades de encontrar material sobre a história de Conceição de Salinas. Sacramento (2019) entrevistou Almir Oliveira, um dos maiores escritores e pesquisadores sobre a história de Salinas da Margarida. Elionice Conceição Sacramento (2019) também concordou que o autor de uma dos maiores livros da história de Salinas da Margarida, Almir Oliveira (2000) não faz qualquer abordagem sobre os impactos da escravização ou até mesmo de existir quilombos na região de Salinas da Margarida.

Em sua pesquisa Sacramento (2019) ressalta não pode aprofundar algumas questões da pesquisa, principalmente sobre a história de Conceição de Salinas, assim, sentimos a ausência de dados e fontes históricas que nos fizessem entender realmente a existência de quilombo ou remanescentes de quilombolas na cidade de Salinas da Margarida, ficando então a questão: Conceição de Salinas foi ou não foi um quilombo ou uma comunidade remanescentes de quilombolas? Pelas nossas leituras e pesquisas, e principalmente através das narrativas dos Senhores e Senhoras do Mar, Conceição de Salinas nunca foi um quilombo.

Em 2010, foi publicada uma obra coletiva, intitulada de "Salinas, o Mar, a Lama e a Vida". Neste livro que apresenta alguns dados históricos, narrativas e histórias de vidas de pessoas da Cidade de Salinas das Margaridas, nenhum autor refere-se à Conceição de Salinas como Quilombo, mas como uma Comunidade Tradicional, nem mesmo Sacramento (2019) que é coautora do livro, discorre sobre ser Conceição de Salinas uma comunidade remanescente de quilombolas. 
Nívia Martins Menezes (2013) em sua pesquisa de Mestrado os "Efeitos Do Programa Bolsa Família Sobre Os Seus Beneficiários: Estudo De Caso Em Salinas Da Margarida/Ba" não apresenta nenhuma família quilombola ou remanescentes de quilombolas em Conceição de Salinas, afirmando que: "No Estado da Bahia 19.896 famílias quilombolas são beneficiárias do PBF (Bolsa Família) segundo dados do MDS (2012), o que equivale a $125 \%$ do total da estimativa de famílias quilombolas no estado. Em relação às famílias indígenas 7.647 recebem o benefício do PBF.

Na pesquisa "Na Maré E Na Escola: Experiências Educativas De Marisqueiras De Salinas Da Margarida-Ba" Hugo Silva Caetano (2013) aborda a experiência de aprendizagem das marisqueiras de Salinas da Margarida-Bahia. A pesquisa é um convite ao cotidiano da pesca e da vida nas comunidades tradicionais de Salinas das Margaridas. Na pesquisa de Caetano (2013) em nenhum momento surge a palavra quilombo, no entanto há 49 referências para a palavra "comunidades', 23 para a palavra" tradicionais" e 33 para a palavra "pesqueira".

Contudo, podemos pontuar que a comunidade de Conceição de Salinas é uma comunidade de homens e mulheres ancestrais, pescadores e marisqueiras sim, mas não encontramos fontes histórias para uma afirmativa quilombolas. Todavia o texto de Sacramento (2019) é um texto que nos remete ao mar, a vida das mulheres do mar e ao povo da maré, tais narrativas apresentadas do texto demostram a luta de homens e mulheres pela sobrevivência em meio a um país que é racista e desigual.

Notamos claramente que Conceição de Salinas também, vive uma situação parecida com a descrita pelo pesquisador Nilson Thomé, professor de História que afirma:

Há um decreto, que inovou ao apresentar a autoidentificação (auto atribuição ou autodefinição) como critério para reconhecimento de uma comunidade quilombola, dispensando a exigência de comprovação documental da descendência de escravos fugidos e da posse histórica ininterrupta sobre a terra, para que terras sejam

RC: 84996

Disponível em: https://www.nucleodoconhecimento.com.br/educacao/saberes-do-mar 
tituladas a negros, onde hoje eles se encontrem, inclusive tenham sido quilombolas ou não, entendimento contra o qual há os que se insurgem pelo absurdo apregoado. (THOMÉ, 2009, p. 120a)

Para o professor Nilson Thomé (2009) esta interpretação não pode ser aceita. A auto atribuição, ou a autodefinição, não pode ser manifestada apenas por palavras das partes interessadas. Tem que ser comprovada. O caso apresentado pelo professor em seu texto "Negros no Contestado sim, quilombos e quilombolas, não!" tem uma similaridade muito grande com a situação de Conceição de Salinas,

pois a própria comunidade apregoa e deixa ver que, ao longo de todo o tempo, que nunca afirmou e nem pôde provar ser remanescente de um quilombo, pois nunca disseram e nem alegaram seus membros que a área era um antigo quilombo. (THOMÉ, 2009, p. 120b)

Neste contexto, como afirma Nilson Thomé (2009) de nada adianta, para efeito de se valerem da Constituição, produzirem narrativas, textos se os (alguns) membros da comunidade (Conceição de Salinas) autoproclamarem-se quilombolas, se isso eles nunca foram. Na perspectiva de Nilson Thomé (2009) existe uma clara e evidente confusão de entendimento sobre significados e sobre o sentido de pertencimento.

Senhor do Mar Arraia (88 anos), nascido em Conceição de Salinas, foi vereador de Salinas da Margarida. A relação com mar é muito forte, já pescou, teve rede, canoa viveu e sobreviveu da maré. Ao falar de sua ancestralidade e sobre a declaração que Conceição de Salinas foi um quilombo e é remanescente de quilombola, Senhor do Mar Arraia (88 anos) afirma: "Eu nunca ouvi comentar sobre isso, é a primeira vez que estou ouvindo falar, eu nunca ouvi falar nada nesse sentido".

A narrativa do Senhor do Mar Arraia (88 anos) como muitas outras narrativas que ouvimos em Conceição de Salinas, Cairu, Barra do Paraguaçu e na sede em

RC: 84996

Disponível em: https://www.nucleodoconhecimento.com.br/educacao/saberes-do-mar 
Salinas, nos surpreendeu, pois ficou claro pelas vozes destes Senhores e Senhoras ancestrais a não existência de quilombo nesta região e tão pouco ser Conceição de Salinas, uma comunidade remanescente de quilombolas. Para Nilson Thomé (2009) O movimento pós-modernista em prol da caracterização da população brasileira busca:

atribuir aos descendentes de negros a condição de quilombolas (não eram), como se o lugar tivesse sido um quilombo (não foi), trata-se, evidentemente, de mais uma iniciativa orquestrada por determinadas organizações não-governamentais, ligadas aos movimentos sociais de ideologias diferentes. (THOMÉ, 2009, p. 120c)

Neste mesmo entendimento, a Senhora do Mar Aratu (89 anos), uma das Senhoras do Mar, portadora de saberes ancestrais, líder e orientadora espiritual, benzedeira desde a sua juventude, onde começou sua devoção a Nossa Senhora das Candeias, devota também de Yemanjá, que anualmente realiza no dia 02 de fevereiro a tradicional festa de lemanjá em Salinas da Margarida e missa e procissão para Nossa Senhora das Candeias, ressaltou que em todos os seus anos de vida, nunca ouviu falar que existia quilombo em Salinas da Margarida ou em Conceição de Salinas "não sei disso não, aqui nunca foi quilombo" afirmou a Senhora do Mar Aratu (89 anos).

Almir de Oliveira (2000) relata a história, a memória, e diversos fatos históricos do Município de Salinas demonstrando, como outros pesquisadores aqui já citados, a não existência de evidências da formação de Quilombos em Conceição de Salinas. Flávio dos Santos Gomes (2015) ressalta que qualquer pessoa com mais de 80 anos vão apresentar memórias e narrativas importantes sobre as marcas vividas pelas suas ancestralidades e tais memórias, marcadas pelas ancestralidades são lastros de inúmeras pesquisas cientificas no Brasil, mas nas nossas entrevistas não encontramos nada que pudéssemos afirmar a existência de quilombo nesta região.

RC: 84996

Disponível em: https://www.nucleodoconhecimento.com.br/educacao/saberes-do-mar 
A Senhora do Mar da Rede (114 anos) descreveu sua vida e jornada em Salinas da Margarida, mesmo com mais de 100 anos, lúcida e sorridente, ao falar da sua ancestralidade, de seus pais, avós e da sua própria infância nada narrou sobre a existência de quilombo em Conceição de Salinas. Uma pessoa desta idade certamente apresentaria alguma memória.

\section{A PANDEMIA DA COVID-19 EM SALINAS DA MARGARIDA}

Os primeiros casos da Covid-19 ocorreram na cidade de Wuhan localizada na China e espalhou-se pelo mundo. A pandemia da covid-19 tem registrado mais de mil óbitos por dia no Brasil, totalizando mais de 300 mil mortes até abril de 2021. Na Bahia houve o registro de mais de 15 mil mortes e em Salinas da Margarida registou-se 11 óbitos e 1.199 casos confirmados, segundo o boletim de 13 de abril de 2021.

Depois de muita luta pela sobrevivência e com o aumento dos casos de pessoas infectadas pelo coronavírus a solução seria a vacinação em massa da população, evitando as centenas de mortes que estão acontecendo diariamente. Devido a pandemia, desde março de 2020, inúmeras atividades foram paralisadas no município de Salinas da Margarida, incluindo as aulas escolares, o turismo e diversas atividades econômicas por conta da pandemia.

Em janeiro de 2021, as primeiras vacinas começam a chegar às cidades brasileiras trazendo alivio e esperança. Já no município de Salinas da Margarida, as primeiras doses contra a covid-19 chegaram no dia 19 de janeiro de 2021 e a primeira salinense a receber a vacina contra a covid-19 foi à enfermeira Aline Correia de Lima. (Dados da Secretaria de Saúde do Município de Salinas da Margarida)

Um caso que chamou a nossa atenção já no fechamento deste texto, foi uma Nota De Esclarecimento publicada no dia 25 de março de 2021, pela prefeitura Municipal

RC: 84996

Disponível em: https://www.nucleodoconhecimento.com.br/educacao/saberes-do-mar 
de Salinas da Margarida com considerações sobre a vacina contra a covid-19 e sobre a situação da suposta identidade quilombola em Conceição de Salinas, algo que para nós pesquisadores já estava claro: não existem evidências históricas nem nas narrativas dos Senhores e Senhoras do Mar que configura tal situação de remanência quilombola na região.

A nota deixa evidente algumas questões: (01) Considerando que o INCRA não emitiu Relatório Técnico de Identificação e Delimitação dessa comunidade (Conceição de Salinas), não sendo possível ao Município, confirmar a autenticidade da Autodefinição. A nota ainda declara que 386 moradores de Conceição de Salinas se Autodeclararam Quilombolas e foram vacinados através das prerrogativas do Plano Estadual de Vacinação que identifica como grupo prioritário Povos E Comunidades Tradicionais E Ribeirinhas.

Vale ressaltar que a comunidade de Conceição de Salinas como outras comunidades da Baia de Todos os Santos, são comunidades tradicionais e não essencialmente quilombola. A comunidade de Baiacu em Vera Cruz, constituída em 1560 e a comunidade de Misericórdia na llha de Itaparica e diversas outras comunidades, são sim tradicionais e mereciam também a oferta da vacinação, algo que não ocorreu.

No entanto, ao ser noticiada a vacinação em Conceição de Salinas, algumas pessoas foram receber a vacina contra a covid-19, pela vida, pela família, pelos netos e netas, pela sobrevivência, pelo desejo de continuar vendo o mar, a maré e de se proteger da covid-19, pela necessidade de sobrevivência, pelo medo da morte e pela imposição burocrática tiveram que assinar um terno se Autodeclarando Quilombola, não por uma identificação histórica, mas pela vida. Francisco Barbosa viu de perto a vacinação destas pessoas, pois estava no local da vacinação e notou que muitas nem sabiam o teor da documentação que estavam assinando e outras só estavam ali por conta da vacina. Algumas, mesmo morando na comunidade não eram remanescentes 
quilombolas, não tinha relação de pertencimento nem mesmo com a pesca, mas naquele momento a única forma de tomar a vacina rapidamente era a Autodefinição.

Em 2014, o Ministério Público Estadual da Bahia fez uma investigação que resultou em 8 alunos expulsos por suspeita de fraude em cotas reservadas para quilombolas (descendentes de escravos) na Universidade Estadual do Sudoeste da Bahia (UESB). Os alunos não eram quilombolas nem remanescentes de quilombolas, usaram deste artificio para o ingresso na universidade.

Notamos também, em uma leve pesquisa na internet que diversos processos e ações têm acontecido no Brasil, resultante deste tipo de crime (Autodeclarando Quilombola) sem ser, sem pertencimento e sem história. Tal fato deslegitima as comunidades que realmente são remanescentes de quilombolas. E devido à pandemia da covid-19, temos notado diversos tipos de crimes: rouba de vacinas, aplicação falsa da vacina por enfermeiros e enfermeiras e a venda ilegal da vacina contra a covid-19.

O desespero tem tomando o coração da população, principalmente os mais vulneráveis, os que estão nos grupos de riscos (idosos e pessoas com comorbidades). Ser vacinado e vacinada é um alento, a vacina é por hora a melhor e maior solução contra a covid-19. A vacina é a esperança para dias melhores, para um futuro melhor, principalmente pela falta de leitos de UTI em diversos estados e a Bahia já chegou a atingir quase que $90 \%$ dos leitos de UTI ocupados em abril de 2021 , um fato que culmina na ansiedade e no desejo de ser vacinado e vacinada, antes de ser contaminado pela segunda onda de contaminação do coronavírus que tem devastado o Brasil.

E foi assim, que, pela vida, pela família, pelos netos e netas, pela sobrevivência, pelo desejo de continuar vendo o mar, a maré e de se proteger da covid-19, muitos moradores de Conceição de Salinas assinaram um termo de Autodeclararam 
Quilombola, que era obrigatório para o recebimento do imunizante do coronavírus. Algumas vacinas que chegaram para o município de Salinas da Margarida, estavam dentro do Plano Estadual de Vacinação destinadas para Povos E Comunidades Tradicionais E Ribeirinhas e muitos moradores de Conceição de Salinas, tiveram que assinar este termo de Autodeclararam Quilombola, sem nem mesmo saber o que estavam assinando. Mas era uma possibilidade de se imunizar e assim o fizeram. Aqui temos um ditado que diz : "a necessidade faz o peixe pular". O que fazemos e como fazemos, tem suas bases na necessidade. Foi o que percebemos neste cenário pandêmico em Conceição de Salinas.

E assim, a nossa próxima caminhada levou-nos a uma comunidade chamada de Barra do Paraguaçu.

\section{BARRA DO PARAGUAÇU}

Barra do Paraguaçu é um belo distrito da cidade de Salinas da Margarida, recebe este nome por causa do rio Paraguaçu, um rio histórico e importante na Bahia. O nome Paraguaçu é indígena (tupi) significando "rio grande". O rio Paraguaçu tem sua nascente no morro do Ouro, na Chapada Diamantina, passando por cidades como Castro Alves, Governador Mangabeira, São Félix (Bahia), Cachoeira Maragogipe e muitas outras, desembocando na Baía de Todos-os-Santos.

\section{ANCESTRALIDADE E MARITIMIDADE EM SALINAS DA MARGARIDA}

A Maritimidade de Salina da Margarida está presente nas praias e manguezais banhados por águas mornas dentro da Baia de Todos os Santos. O cenário é perfeito para o turismo, onde o mar é o ator principal. Mar que sustenta, alimenta, diverte, alegra, agrega, acalma ...Isso é a maritimidade.

RC: 84996

Disponível em: https://www.nucleodoconhecimento.com.br/educacao/saberes-do-mar 
Silvano Sulzart (2016) descreve no livro "Docência das Águas: diversidade cultural, travessias e maritimidade na llha de Itaparica" que nascer e viver no mar tem suas vantagens. Logo cedo, em sua meninice, você aprende a nadar, a gostar de andar descalço, a sentir o sol sobre o corpo, e este corpo se acostuma com o sol, com a temperatura. Você torna-se perito no ritmo e no tempo do mar, conhece as ondas, as correntes, barcos ancorados ali, à beira-mar, você sabe a direção do vento, se familiariza com as mudanças do mar, vive a apreciar o gosto bem salgadinho das coisas - devido à salinidade - e o "relógio" da maré impera sobre os seus sentidos."

Na perspectiva de Silvano Sulzart (2016) a maritimidade tem diferentes aspectos, dentre eles o aspecto cultural, o aspecto simbólico, o aspecto de subsistência e o aspecto físico da biodiversidade. O seu aspecto cultural marca-se presente na culinária, voltada para os "frutos do mar", para a pesca artesanal e para todas as práticas sociais realizadas no mar. No aspecto simbólico está a relação entre a religiosidade e o mar, o mar como lugar e morada de deuses. O mar para os povos que se utilizam dele não é somente o lugar de subsistência, existe uma relação mística e de respeito com o mar.

Para Silvano Sulzart (2016) a maritimidade no seu aspecto físico em Salinas da Margarida é composta por uma rica biodiversidade de moluscos, crustáceos, equinodermas, corais e algas. Podemos também perceber a presença de diversos mamíferos aquáticos, dentre eles, Sotalia guianensis - o boto da Baía de Todos os Santos e Megaptera navaeangliae - a baleia jubarte. Ubaldo Osório (1979) relata a presença de baleias jubartes no interior da Baía de Todos os Santos.

A maritimidade espalha-se por Salinas da Margarida, penetra as escolas, casas, igrejas, centros religiosos, empresas, organizações sociais e molda o viver de homens, mulheres, meninos e meninas. O mar compõe o cotidiano da vida em Salinas em diferentes formas e contextos.

RC: 84996

Disponível em: https://www.nucleodoconhecimento.com.br/educacao/saberes-do-mar 
A vida em Salinas da Margarida está ligada diretamente ao mar, ainda que muitas pessoas não o reconheçam como vetor importante para a sustentabilidade, economia e desenvolvimento local. O mar centraliza as atividades de lazer, as atividades sociais e as cerimônias espirituais de diferentes religiões. Todos em Salinas da Margarida estão envolvidos na maritimidade, até o ar da cidade, úmido e carregado de salinidade, dita o viver e a saúde.

E assim, na praia, no cais, nos barcos, nas pontes, no mar, tudo conspira a favor da influência da maritimidade, que afeta não só a vida cultural e social, mas também a saúde. Morar em Salinas é viver com a salinidade, maritimidade e com o tempo da maré. O mar é cultura e muitos comportamentos e práticas sociais de Salinas são realizados e influenciados pelo mar.

\section{ALGUMAS CONSIDERAÇÕES}

O Coletivo Saberes do Mar notou que existe uma emergência de se estudar profundamente a história, a cultura e os elementos da ancestralidade em Salinas da Margarida, mobilizando pesquisadores, estudantes e professores para um mergulho nos saberes do mar, na vida pesqueira, na ancestralidade, cultura e religiosidade que permeia esta cidade.

Quanto à ancestralidade, notamos a força da cultura presente na cidade de Salinas da Margarida. Outro detalhe foi que nesta pesquisa, não encontramos evidências nas narrativas dos entrevistados, na literatura pesquisada e nem em fatos históricos da existência de quilombo ou remanescentes de quilombolas em Conceição de Salinas. Uma situação que carece de mais pesquisas, leituras e investigações, tendo em vista, que a comunidade de Conceição de Salinas não se reconhece como quilombolas e nem como remanescentes de quilombolas mesmo sendo certificada pela Fundação Palmares em 2017. Notamos que Conceição de Salinas é de fato uma comunidade

$\mathrm{RC}: 84996$

Disponível em: https://www.nucleodoconhecimento.com.br/educacao/saberes-do-mar 
ancestral, negra e de uma riqueza cultural inigualável, mas pelas entrevistas e narrativas, quilombola, não.

Sendo assim, coadunamos com Nilson Thomé (2009), que apresentou um estudo intitulado de "Negros No Contestado, Sim! Quilombos E Quilombolas, Não". Tal estudo apresenta uma similaridade com Salinas da Margarida, quanto a não existir evidência de quilombo ou remanescentes de quilombolas em Conceição de Salinas tendo em vista as narrativas analisadas. O artigo de Nilson Thomé (2009) revela a discordância de quem produz História Regional quanto à existência de quilombos e de quilombolas na região do Contestado em Santa Catarina, tal fato foi notado também em Salinas das Margaridas Bahia, existindo outros meios e caminhos para a sociedade de Salinas da Margarida resgatar a dívida que tem para com o resultado nefasto do fenômeno da escravidão na Bahia, no Brasil e na própria cidade de Salinas da Margarida, uma terra linda, de um povo ancestral, de saberes do mar e da terra.

\section{REFERÊNCIA BIBLIOGRÁFICA}

BARBOSA, Francisco. O Processo de Emancipação Política de Salinas da Margarida no ano de 1962. Salinas da Margarida. Monografia. Universidade do Estado da Bahia, 2015.

BAHIA. Plano Estadual de Vacinação - Secretário de Saúde do Estado da Bahia. Disponível em http://www.saude.ba.gov.br/wp-content/uploads/2021/01/Plano-deVacinacao-Covid-19.pdf. Acessado em 29 de Março de 2021.

BENJAMIN, Walter. O narrador: considerações sobre a obra de Nikolai Leskov. Magia e técnica, arte e política: ensaios sobre literatura e história da cultura. São Paulo: Brasiliense, 1994, p. 197-221

RC: 84996

Disponível em: https://www.nucleodoconhecimento.com.br/educacao/saberes-do-mar 
BERTAUX, Daniel. Narrativas de vida: a pesquisa e seus métodos. Natal: EDUFRN; São Paulo: Paulus, 2010.

BITTENCOURT, Mário . Oito alunos são expulsos da Uesb por fraude em cota quilombola.

Disponível

em: https://www.correio24horas.com.br/noticia/nid/oito-alunos-sao-expulsosda-uesb-por-fraude-em-cota-quilombola/. Acesso em 04 de abri de 2021.

BRASIL. Convenção n 169 da OIT sobre Povos Indígenas e Tribais. Disponível em

https://www.oas.org/dil/port/1989\%20Conven\%C3\%A7\%C3\%A30\%20sobre\%20Pov os\%20Ind\%C3\%ADgenas\%20e\%20Tribais\%20Conven\%C3\%A7\%C3\%A30\%20OIT \%20n\%20\%C2\%BA\%20169.pdf. Acessado em 29 de março de 2021.

CAETANO, Hugo Silva. Na Maré e na Escola: Experiências educativas de marisqueiras em Salinas da Margarida. 2013. Dissertação (Mestrado em Educação e Contemporaneidade) - Universidade do Estado da Bahia, 2013.

CASTELLUCCI JUNIOR, Wellington. Pescadores e Roceiros: escravos e forros em Itaparica na segunda metade do século XIX.. 1ㄹ. ed. São Paulo: Annablume Editora Ltda/Fapesb, 2008. v. 01. 300p .

CASTELLUCCI JUNIOR, Wellington. Pescadores da Modernagem: Cultura, Trabalho e Memória em Tairu, Bahia. 1960-1990. 1‥ ed. São Paulo: AnnaBlume editora, comunicação Itda./ Fapesb, 2006. v. 01.175p .

CASTELLUCCI JUNIOR, Wellington; SOUZA, Edinélia Maria Oliveira ; BARRETO, Virgínia Queiroz . Entre veredas e arrabaldes:escravos e libertos na Comarca de Nazaré das Farinhas durante o oitocentos e no Pós-abolição. 01. ed. Belo Horizonte: Fino Traço, 2014. v. 01. 325p.

RC: 84996

Disponível em: https://www.nucleodoconhecimento.com.br/educacao/saberes-do-mar 
CASTELLUCCI JUNIOR, Wellington. Caçadores de baleia: armações, arpoadores, atravessadores e outros sujeitos envolvidos nos negócios do cetáceo no Brasil.. 1‥ ed. São Paulo: Annablume EDITORA Ltda, 2009. v. 01. 210p.

CASTTELUCCI JUNIOR, Wellington. Pescadores e baleeiros: a atividade da pesca da baleia nas últimas décadas dos oitocentos Itaparica. Revista Afro-Ásia, Salvador, n. 33 , p. 133-168, dez. 2005. Disponível em: http://www.afroasia.ufba.br/pdf/afroasia33_pp133_168_Wellington.pdf. Acesso em: 10 set. 2010.

DIEGUES, A. C. Pescadores, camponeses e trabalhadores do mar. São Paulo: Ática, 1983.

DIEGUES, Antonio Carlos. Ilhas e mares. Simbolismo e imaginário. São Paulo: HUCITEC, 1998.

DIEGUES, Antonio Carlos. A interdisciplinaridade nos estudos do mar: o papel das ciências sociais. In: SEMANA DE OCEANOGRAFIA, 15., 2003, São Paulo. Conferência, Anais... São Paulo: Instituto Oceanográfico da USP, 2003.p. 145-173.

DIEGUES, A. C. (org.) A imagem das águas. São Paulo: Hucitec, Núcleo de Apoio à Pesquisa sobre Populações Humanas e Áreas Úmidas Brasileiras/USP, 2000

DOMINICÉ, Pierre - A biografia educativa: instrumento de investigação para a educação de adultos. In: NÓVOA, António e FINGER, Mathias - 0 método (auto)biográfico e aformação. Lisboa: MS/DRHS/CFAP, 1988.

GERMANI, Guiomar I. OLIVEIRA, Gilca G. (coord). "Comunidade Quilombola Pesqueira Conceição De Salinas". Relatório Técnico Preliminar. Grupo de Pesquisa GeografAR/POSGEO/UFBA-CNPq. Salvador, 2019. 
GOMES, Flávio dos Santos. A hidra e os pântanos: mocambos, quilombos e comunidades de fugidos no Brasil (séculos XVII-XIX). São Paulo: Ed. UNESP; Ed. Polis, 2005.

GOMES, Flávio dos Santos. Mocambos e quilombos: uma história do campesinato negro no Brasil. São Paulo: Claro Enigma, 2015.

GOMES, Flávio dos Santos. Um Recôncavo, dois sertões e vários mocambos: quilombos na Capitania da Bahia (1575-1808). Revista História Social, Campinas, São Paulo, n², 25-54, 1995.

HOBSBAWM, Eric. Era dos Extremos: O breve século XX, 1914-1991. São Paulo: Companhia das Letras, 1998. P. 145-146.

KUHN, Ednizia Ribeiro A. Terra e água: Territórios dos Pescadores artesanais de São Francisco do Paraguaçu - Bahia. 2009. 173 f. Dissertação (Mestrado em Geografia) - Universidade Federal da Bahia, Salvador, 2009.

LOPES, Nei. Enciclopédia brasileira da diáspora africana. São Paulo: Selo Negro, 2004

MENEZES, Nívia Martins. Efeitos do Programa Bolsa Família sobre os seus beneficiários: estudo de caso em Salinas da Margarida/Ba/ Nívia Martins Menezes . Dissertação (Mestrado) - Universidade Católica do Salvador. Superintendência de Pesquisa e Pós-Graduação. Mestrado em Planejamento Territorial e Desenvolvimento Social - Salvador, 2013. $130 \mathrm{f}$.

MINAYO, Maria Cecília de Souza (org.). Pesquisa Social. Teoria, método e criatividade. 18 ed. Petrópolis: Vozes, 2001. 
OLIVEIRA, Almir de Salinas da Margarida Notícias Históricas/Almir de Oliveira Araguari, MG: Minas Ed. 2000.

OLIVEIRA, Eduardo David de. Filosofia da ancestralidade como filosofia africana: Educação e cultura afro-brasileira. Revista Sul-Americana de Filosofia e Educação. Número 18: maio-out/2012.

A epistemologia da ancestralidade. Revista Entrelugares - Revista de Sociopoética e abordagens afins, ISSN 1984-1787, 2009 - Disponível: acesso em 18 de setembro 2015.

. A ancestralidade na encruzilhada. Curitiba: Editora Grafica Popular, 2007

OSÓRIO, Ubaldo. A Ilha de Itaparica: história e tradição. Salvador: Fundação Cultural do Estado da Bahia, 4를 ed, 1979.

PEDRÃO, Fernando. A Baía de Todos os Santos na realidade do imaginário da sociedade baiana. in: CAROSO, Carlos; PEREIRA,Cláudio; TAVARES , Fátima. Baía de Todos os Santos : aspectos humanos . EDUFBA Salvador:, 2011.

PEREIRA, Edimilson de Almeida. Malungos na escola: questões sobre culturas afrodescendentes e educação. São Paulo: Paulinas, 2007.

PERRONE, Maria da Conceição Costa. Os caboclos de Itaparica: história música e simbolismo. 1995. 201 f. Dissertação (Mestrado em música) - Universidade Federal da Bahia, Salvador, 1996.

PINSKY, Bassanezi Carla , org. Novos temas nas aulas de História. São Paulo, Editora Contexto, 2009, 224 pp., ISBN 9788572444187. 
RABINOVICH, E. P.; GALLO, P. R. (2005). Estudo das famílias de uma comunidade quilombola do Carmo, São Roque, SP. Em J. C. Petrini \& V. R. S. Cavalcanti (Orgs.),

SOUZA, E. C.; MIGNOT, A. C. V. (Orgs.). Histórias de vida e formação de professores. Rio de Janeiro: Quartet; FAPERJ, 2008.

SOUSA, Eliseu Clementino de. A arte de contar e trocar experiências: reflexões teórico-metodológicas sobre história de vida em formação. Revista Educação em Questão, Natal, v.25, n. 11, p. 22 - 39, jan./abr., 2006.

THOMPSON, Edward Palmer. Costumes em comum: estudos sobre a cultura popular tradicional. São Paulo: Companhia das Letras, 1998.

THOMÉ, N. Negros no contestado, sim! Quilombos e quilombolas, não!. Ágora : Revista De divulgação científica, 16(1), p. 108-124.

SACRAMENTO, Elionice Conceição (org). Salinas: o mar, a lama, a vida. Grupo Gaivotas e Comunidades Tradicionais. Produção Independente. Salinas da Margarida-BA, 2010.

SACRAMENTO, Elionice Conceição. Da diáspora negra ao território das águas: ancestralidade e protagonismo de mulheres na comunidade pesqueira e quilombola Conceição de Salinas-BA. 2019. 187 f., il. Dissertação (Mestrado em Desenvolvimento Sustentável)—Universidade de Brasília, Brasília, 2019.

SALINAS DA MARGARIDA. Nota De Esclarecimento. Disponível em www.salinasdamargarida.gov.br. Acessada em 29 de março de 2021.

SULZART, Silvano. Docência das Águas: Diversidade Cultural, Maritimidade e Travessias na llha de Itaparica. Editora CRV. Curitiba. 2016. 
WEFFORT, Francisco 0 populismo na política brasileira. $5^{\text {a }}$ ed. Rio de Janeiro: Paz e Terra, 2003.

Enviado: Março, 2021.

Aprovado: Maio, 2021.

RC: 84996

Disponível em: https://www.nucleodoconhecimento.com.br/educacao/saberes-do-mar 